WOJCIECH SZAFRAŃSKI (Poznań)

\title{
Nauczanie prawa w Poznaniu w czasach stanisławowskich
}

W II połowie XVIII w. Poznań stanowił czwarte pod względem ludności miasto w Koronie (po Warszawie, Krakowie i Lublinie), wyróżniające się skomplikowanym układem prawno-administracyjnym. Sąsiednie tereny, będące faktycznie przedmieściami miejskimi, stanowiły konglomerat jurydyk będących własnością kościelną czy szlachecką ${ }^{1}$. Jednocześnie po okresie powolnego wzrostu liczby ludności w czasach saskich miasto ponownie zaczęło pustoszeć w początkach panowania Stanisława Augusta. W pierwszym rzędzie był to efekt działań militarnych prowadzonych w początku lat 70. XVIII w. przez wojska pruskie i rosyjskie. W 1770 r. do Poznania wkroczyli Rosjanie, niszcząc przedmieścia podlegające jurysdykcji miejskiej, w $1771 \mathrm{r}$. miasto zostało zajęte na dwa lata przez Prusaków, dokonujących kolejnych zniszczeń. W latach 1773-1775 ponownie w Poznaniu stacjonowały wojska rosyjskie, co przekładało się na wzrost zadłużenia miasta i jakikolwiek brak jego rozwoju demograficznego ${ }^{2}$. Szczegółowe określenie ludności Poznania w tym okresie jest utrudnione, zważywszy na odmienne traktowanie przez poszczególnych autorów przedmieść Poznania jako należących lub nie należących do miasta, jak i nie zawsze precyzyjny system przelicznikowy tzw. dymów. Najbardziej przekonujące wydają się ustalenia W. Rusińskiego i M. Kędelskiego wskazujących na liczbę 9-10 tys. mieszkańców w latach 1775-17803. Badania nad strukturą narodowo-wyznaniową wskazują, iż w tym okresie ponad $30 \%$ ludności miasta stanowili Żydzi, a 20\% Niemcy ${ }^{4}$. Mieszkańcy Pozna-

1 Patrz szerzej M. Kędelski, Rozwój demograficzny Poznania w XVIII i na początku XIX wieku, Poznań 1992, s. 70-77.

2 Ibidem, s. 71.

3 Patrz: W. Rusiński, Rynek lokalny Poznania w końcu XVIII wieku, „Poznańskie Roczniki Ekonomiczne" 1970, t. 23, s. 11; M. Kędelski, op. cit., s. 72.

${ }^{4}$ M. Jabczyński, Statystyka miasta Poznania w roku 1780 ułożona na podstawie spisu dokonanego przez poznańska Komisję Dobrego Porządku, „Rocznik PTPN” 1911, t. 37, s. 94, M. Kędelski, op. cit., s. 111-117. 
nia zajmowali się głównie działalnością handlową i rzemieślniczą ${ }^{5}$, jednakże zaskakujący jest stosunkowo wysoki odsetek tzw. ludzi luźnych i żebraków sięgających w czasach spisu statystycznego opracowanego przez Komisję Skarbową Obojga Narodów w 1789 r. odpowiednio 20\% i 4\% ogółu ludności chrześcijańskiej zamieszkującej miasto ${ }^{6}$.

Poznań stanowił jednak w czasach stanisławowskich silny ośrodek szkolnictwa $\mathrm{w}$ Wielkopolsce i $\mathrm{w}$ kraju, co wiązało się gównie $\mathrm{z}$ tradycjami nauczania w powstałych jeszcze w XVI w. szkołach: Akademii Lubrańskiego (podległej ówcześnie krakowskiemu uniwersytetowi) oraz Kolegium Jezuickiego założonego przez Jakuba Wujka ${ }^{7}$. Druga połowa XVIII w. stanowiła czas silnej konkurencji obu szkół i walki o przetrwanie choćby jednej z nich poprzez podniesienie jej do rangi uniwersytetu. Znaczącą rolę $\mathrm{w}$ tym procesie odgrywała Komisja Edukacji Narodowej, jak i bieżąca polityka państwa, na którą wpływ miała kasata zakonu jezuitów oraz reformy szkolnictwa, w którą uwikłana była Akademia Krakowska - żywotnie zainteresowana utrzymaniem w Poznaniu zaledwie własnej kolonii akademickiej w postaci Akademii Lubrańskiego i zahamowania procesu powstania w tym mieście jakiekolwiek szkoły wyższej. Akademia Lubrańskiego traktowana była przez uniwersytet jako własna filia, co dostrzegalne było nie tylko w statucie z $1619 \mathrm{r}^{8}$, ale jeszcze silniej w nowych statutach z 1746 r. Dopiero jednak przejęcie zwyczajowych uprawień kapituły katedralnej poznańskiej poprzez utworzenie urzędu prowizora kolonii poznańskiej przez uniwersytet w 1766 r. stanowiło najistotniejszy punkt na drodze całkowitego uzależnienia dawnej Akademii Lubrańskiego przez Akademią Krakowską ${ }^{9}$. Każdorazowo dyrektorem tej Akademii zostawał jeden z profesorów krakowskich, wybierany przez konwokację profesorów Uniwersytetu Krakowskiego i zatwierdzany przez rektora. Kapituła poznańska miała jedynie prawo akceptacji krakowskiego kandydata, które to uprawnienie znacznie osłabło począwszy od wejścia w życie statutów w 1746 r. ${ }^{10}$ Każdorazowo na to stanowisko miał być wybierany profesor prawa, tym samym do jego obowiązków poza tymi wynikającymi z peł-

${ }^{5}$ Poznań był wtedy ważnym miejscem w systemie wewnątrzkrajowych szlaków handlowych - patrz szerzej K. Kuklińska, Handel Poznania w drugiej połowie XVIII wieku, Warszawa-Poznań 1976.

${ }^{6}$ M. Kędelski, op. cit., s. 103-106.

7 Odnośnie do założenia obu szkół patrz szerzej. D. Żołądź-Strzelczyk, Szkoły poznańskie w okresie przedrozbiorowym, „Kronika Miasta Poznania” 2001, z. 4, s. 14-27 oraz M. Nowicki, Działalność oświatowa i naukowa Akademii Lubrańskiego w XVII i XVIII w., Poznań 2011, s. 50-57 (maszynopis pracy doktorskiej).

8 Patrz Statuta Akademii Lubrańskiego z 1619 r. (thum. A. Pawlaczyk), „Kronika Miasta Poznania" 1999, z. 2, s. 228-235.

${ }^{9}$ Patrz szerzej M. Nowicki, op. cit, s. 105-106.

${ }^{10}$ M. Nowicki, op. cit., s. 115. 
nienia funkcji dyrektora (rektora), należały wykłady z prawa i praktycznie był on jedynym nauczycielem tych przedmiotów w Akademii ${ }^{11}$. W czasach stanisławowskich miała ona zaledwie trzech dyrektorów: Stanisława Michała Ficzkiewicza (1764-1767), Karola Marxena (1767-1770) ${ }^{12}$ oraz wybitnego prawnika Franciszka Minockiego (1770-1780) - ostatniego, 52 rektora tej szkoły. Zważywszy na ogólny poziom nauki i nauczania prawa przed reformami KEN w Rzeczpospolitej, to na tym tle działalność naukowa Franciszka Minockiego wygląda dość dobrze. Będąc w Poznaniu, opublikował on swoją najbardziej znaną pracę o crimen laese maiestatis (w 1775 r.), ale także trzy mniej znane prace będące efektem działalności nie tylko naukowej, ale i dydaktycznej Minockiego w zakresie prawa kanonicznego: Processus iudiciarius fori ecclesiastici (1778 r.) - obszerne dzieło o procesie kanonicznym dla praktyków - zawierającym formuły procesowe $\mathrm{z}$ akt sądowych, którą to pracę Minocki kazał po wydrukowaniu z niewiadomych powodów zniszczyćc ${ }^{13}$; Dissertatio Iuridica de nullitate processus (1778 r.) - dotycząca przyczyn i skutków nieważności czynności procesowych i orzeczeń sądowych w prawie kanonicznym ${ }^{14}$. O wiele większą popularnością cieszyła się praca Minockiego pt. Terminorum iuris canonico-civilis interpretatio (wyd. I - 1773 r., wyd. II - 1775 r.), będąca kompendium najważniejszych pojęć prawa polskiego (w układzie alfabetycznym) opartego na prawie rzymskim i kanonicznym $^{15}$. Nie pozostawia żadnych wątpliwości, iż był to rodzaj pomocy dydaktycznej i efekt prac Minockiego jako wykładowcy. Z tego punktu widzenia warto przyjrzeć się, jak wyglądało nauczanie prawa w Akademii Lubrańskiego w czasach trzech ostatnich rektorów. Ustalenia poczynione przez Michała Nowickiego pozwalają przyjąć, iż Akademia Lubrańskiego w rzeczywistości podzielona była na dwa wydziały: humanistyczny i publiczny. W pierwszym uczono podstaw w oparciu o klasy gramatyki, poetyki i retoryki. Wykłady publiczne obejmowały takie przedmioty jak: teologia spekulatywna, teologia moralna, filozofia, matematyka i prawo ${ }^{16}$. W praktyce wykłady w poszczególnych latach bardzo się różniły tak co do pozycji poszczególnych przedmiotów, jak rzeczywistego ich odbywania, a także samej treści. Analiza po-

11 Patrz J. Wiesiołowski, Krakowscy profesorowie Akademii Lubrańskiego. Materiały, „Kronika Miasta Poznania" 1999, z. 2, s. 299-324.

12 Wtedy uczniem Akademii był m.in. Jan Śniadecki.

13 Według S. Salmonowicza obecnie jeden znany egzemplarz znajduje się w BJ sygn. 10832.

14 Praca niniejsza też znana jedynie w jednym egzemplarzu przechowywanym w Ossolineum. Patrz S. Salmonowicz, Franciszek Minocki (1731-1784) jako pisarz prawa karnego, [w:] Miscellanea Iuridica złożone $w$ darze Karolowi Koranyiemu w czterdziestolecie pracy naukowej, Warszawa 1961, s. 130.

15 Patrz S. Salmonowicz, op. cit., s. 127-128. Do czasów reform KEN pewnie była ta praca wykorzystywana w szkołach, bo jeszcze w 1779 r. np. w Płocku.

${ }^{16}$ M. Nowicki, op. cit., s. 130-132. 
szczególnych Ordinatio studiorum ${ }^{17}$ oraz Liber convocationum ${ }^{18}$ odnośnie do wykładów z prawa, nie pozostawia wątpliwości o znaczeniu wyłącznie prawa i procesu kanonicznego w nauczaniu w Akademii Lubrańskiego. Wydaje się to zresztą zgodne z samymi założeniami szkoły oraz oczekiwaniami samych uczniów, albowiem na tzw. wydział publiczny trafiały przede wszystkim osoby marzące o karierze w stanie duchownym, względnie chcące się dalej kształcić na uniwersytetach. Uczniowie mający ambicje trafienia np. do palestry kończyli swoją edukację w Akademii Lubrańskiego na etapie wydziału humanistycznego, a więc zasadniczo bez jakichkolwiek wykładów z prawa. Dostępny materiał źródłowy nie pozwala na szczegółową analizę wykładanych materii prawnych, brak bowiem programów na poszczególne semestry. $\mathrm{Z}$ pewnością najwięcej czasu poświęcano prawu i procesowi kanonicznemu, przykładowo w programie wykładów z 1764 r. zawartych w Liber Convocationum $^{19}$, wskazano, iż w soboty i dni świąteczne wykładane mają być Regulae Iuris Bonifacego VIII, a w dni powszednie Processus Iudiciarium Praxi Utriusque Fori Regni Poloniae ${ }^{20}$. Tym samym generalnie wykładano źródła do prawa kanonicznego, w ograniczonym wymiarze natomiast prawo rzymskie, o ile służyło to nauczaniu prawa i procesu kanonicznego. Wykładów z prawa cywilnego krajowego praktycznie nie prowadzono w Akademii, co nie było wyjątkiem, zważywszy, iż nawet na Akademii Krakowskiej nie nauczano prawa krajowego, którego katedrę pod kierownictwem Józefa Januszewicza powołano pod wpływem Hugona Kołłątaja dopiero w latach 80 . XVIII w., a więc wtedy, gdy już Akademia Lubrańskiego przestała istnieće ${ }^{21}$. Warto w tym miejscu zauważyć, iż nauczanie prawa kanonicznego w szkołach praktycznie bardziej ówcześnie się opłacało niż prawa krajowego ${ }^{22}$. Po pierwsze, $\mathrm{z}$ uwagi na rzeczywisty awans w przypadku jego dobrej znajomości, po drugie - z uwagi na powszechne wówczas przeświadczenie o znaczeniu praktyki w sądownictwie świeckim. Zdecydowanie bardziej więc liczyła się od szkolnego nauczania prawa praktyka odbyta w kancelariach połączona z protekcją. Uczniowie widzący swoją przyszłość w palestrze czy sądownictwie rezygnowali ze szkół na poziomie nauki czytania i pisania po łacinie, praktycznie nie będąc w stanie dotrwać do wykładów z prawa odbywanych na wyższych latach i szukali praktyki. Wymownym tego przykładem był Józef

17 Patrz np. J. Marciszowski, Ordinatio studiorum in Collegio Lubransciano, Posnaniae 1756.

${ }^{18}$ Liber Convocationum Inclytea Academiae Posnaniensis - BJ sygn. 247 III.

${ }^{19}$ Liber Convocationum Inclytea Academiae Posnaniensis - BJ sygn. 247 III, p. 36.

${ }^{20}$ Zapewne posługiwano się pracą autorstwa Andrzeja Lipiewicza o tym tytule, rektora Akademii Lubrańskiego w latach 1763-1764.

${ }^{21}$ Odnośnie do starań H. Kołłataja o katedrę prawa krajowego patrz szerzej W. Szafrański, Prace prawnicze Hugona Koltątaja, Poznań 2005, s. 11-35.

22 Odnośnie do nauczania prawa kanonicznego w XVIII w. w szkołach jezuickich patrz przykładowo J. Flaga, Z problematyki nauczania prawa kanonicznego u jezuitów w XVII i XVIII w., „Rocznik Nauk Prawnych” 2002, t. XII, z. 2, s. 37-57. 
Wybicki, który w swych pamiętnikach w pełni oddaje wyobrażenie i prawdę o nauczaniu prawa w kancelariach:

Powszechne mniemanie uważało kancelarię jako szkołę szlachetną, przez którą przejść musiała koniecznie młodzież, przeznaczona z urodzenia do rządów kraju i sprawowania wszelkich urzędów publicznych. Zgoła kancelaria miało to być plemię senatorów, posłów, sędziów itd., źródło wiadomości praw krajowych. (...) Co się tycze nabycia wiadomości, te tylko przypadkowi, albo wrodzonym zdolnościom młodego przypisać można; sama szkoła dać ich nie mogła, bo żadnych prawideł ani organizacji nie miała ${ }^{23}$.

Stan taki był powszechnie krytykowany i wielokrotnie pojawiały się nawet $\mathrm{w}$ instrukcjach sejmikowych żądania ustanowienia szkół iuris prudentiae czy collegium iuridicum ${ }^{24}$.

Trudno jednoznacznie ocenić poziom wykładów, nawet z prawa kanonicznego, w Akademii w czasach stanisławowskich przed 1780 r. Z pewnością miała ona szczęście do dobrych wykładowców prawa, choć nie bez znaczenia pozostaje tutaj kwestia połączenia urzędu rektora (dyrektora) z nominacją spośród prawników. Niemniej sam ówczesny poziom nauki prawa w Polsce pozostawiał wiele do życzenia, czemu próbowała zaradzić KEN. Wcale lepiej sytuacja w tym okresie nie wyglądała w kolegiach jezuickich. Józef Wybicki, który rozpoczynał naukę w szkołach jezuickich, miał o nich dość mierne zdanie: „nie będę opisywał toku edukacji w niższych klasach; był taki sam, jakem wyżej wspomniał; kazano się zawsze pod odmiennymi nazwiskami złej uczyć łaciny, bez żadnej korzyści. Myśleć nie kazano" ${ }^{25}$. Taki obraz był dość powszechny, niemniej kasata zakonu jezuitów spowodowała wiele problemów praktycznych z tzw. szkolnictwem pojezuickim w Polsce. Na terenie Rzeczpospolitej pozostało osiem pełnych kolegiów pojezuickich, w tej grupie znajdowało się też kolegium poznańskie. KEN stanęła przed decyzją odnośnie do kierunku całościowej reformy szkół średnich i wyższych. Sprawę na tyle pilną, gdyż po pierwsze bardzo szybko postępowało rozgrabienie majątku Towarzystwa Jezusowego głównie przez lustratorów, po drugie istniała realna groźba rozpadu kolegiów poprzez wyprowadzki nauczycieli duchownych, a tym samym upadku szkolnictwa średniego w wielu polskich miastach ${ }^{26}$. Całościowa analiza propozycji zmian i dyskusji w łonie samej KEN stanowi osobne

${ }^{23}$ Pamiętnik Józefa Wybickiego, senatora wojewody Królestwa Polskiego wydany z rękopisu przez Edwarda Raczyńskiego, Poznań 1840, t. I, s. 15-17.

${ }^{24}$ Patrz przykładowo instrukcja posłów ziemi warszawskiej z 1776 r. - Biblioteka PAN w Krakowie, rkps 8349, k. 378 oraz A. Abramski, J. Konieczny, Adwokatura w projekcie „Zbioru Praw Sądowych” Andrzeja Zamoyskiego z 1778 roku, „Palestra” 1984, nr 1, s. 48-55.

${ }_{25}$ Pamiętnik Józefa Wybickiego..., s. 9-10.

${ }^{26}$ Patrz K. Mrozowska, Funkcjonowanie systemu szkolnego Komisji Edukacji Narodowej na terenie Korony w latach 1783-1793, Wrocław-Warszawa-Kraków-Gdańsk-Łódź 1985, s. 105-115. 
zagadnienie, niemniej z punktu widzenia niniejszego artykułu, szczególnie ważne wydają się trzy propozycje: Antoniego Popławskiego planującego organizację czterech uniwersytetów po jednym dla każdego z regionów - w tym w Poznaniu dla Wielkopolski; Augusta Sułkowskiego ówczesnego komisarza KEN, proponującego podział procesu kształcenia na dwa etapy - niższy, realizowany w trzech akademiach prowincjonalnych (Poznań, Kraków, Wilno) i wyższy, realizowany przez dwie akademie warszawskie; Józefa Rogalińskiego byłego członka poznańskiego kolegium jezuickiego, zmierzającego do powołania w Poznaniu na bazie kolegium pojezuickiego uniwersytetu ${ }^{27}$.

Najdalej w realizacji swych zamierzeń posunął się Józef Rogaliński, który zyskując poparcie Augusta Sułkowskiego, kanclerza wielkiego koronnego Andrzeja Młodziejowskiego oraz Antoniego Ponińskiego, starał się wywrzeć presję i postawić KEN praktycznie przed faktami dokonanymi. Kolegium pojezuickie dysponowało odpowiednim zapleczem budynkowym, zdolnym do pomieszczenia w jednym miejscu zarówno szkoły wyższej, jak i szkoły wojewódzkiej. Na czele tej pierwszej stanął Józef Rogaliński, podpisujący się już w 1774 r. jako rektor Akademii Wielkopolskiej, choć nie posiadał prawnie niniejszego tytułu ${ }^{28}$. Niemniej KEN także w stosunku do niego posługiwała się tą nomenklaturą i wydawało się, że sprawa formalnego powołania uniwersytetu w Poznaniu jest już przesądzona. Tym bardziej, iż J. Rogaliński zabiegał w KEN o likwidację, względnie poddanie Akademii Lubrańskiego pod zwierzchnictwo rektora Akademii Wielkopolskiej. Dowodem na to może być jeden z punktów tzw. Watpliwości - czyli zapytań do KEN autorstwa Rogalińskiego: „Szkoła w Poznaniu na przedmieściach dependująca od Akademii Krakowskiej, żeby albo wcale zniesiona była według projektu w maju podanego przez ks. Rogalińskiego do P. Komisji Edukacyjnej, albo żeby od rektora akademii Wielkopolskiej zupełnie zależała i żeby rządca jej nie nazywał się (jak dotąd zwykł) rektorem akademii Poznańskiej, żeby ich dwóch nie było z tym tytułem"29. Odpowiedź, której z ramienia KEN udzielił prezes Michał Poniatowski, była jednoznaczna: „To do czasu odłożyć”30. W 1775 r. Józef Rogalińki jako oficjalny wizytator KEN dla szkół wielkopolskich wskazywał w swoim raporcie na konieczność zatrudnienia w Akademii Wielkopolskiej profesora prawa świeckiego i medycyny ${ }^{31}$. Brak więc było kadry do tego, by

27 O tych propozycjach patrz szerzej D. Żołądź-Strzelczyk, Szkoły w Wielkopolsce od średniowiecznych początków do reform Komisji Edukacji Narodowej, Poznań 2010, s. 188-190 oraz H. Pohoska, Wizytatorowie generalni Komisji Edukacji Narodowej. Monografia z dziejów administracji szkolnej Komisji Edukacji Narodowej, Lublin 1957, s. 131.

28 Ibidem, s. 192-194.

29 Raporty generalnych wizytatorów z lat 1774-1782, wyd. T. Wierzbowski, Warszawa 1907, s. 22 .

30 Ibidem.

31 Wizytacja miała miejsce w 1774 r. Raporty generalnych wizytatorów z lat 1774-1782, wyd. T. Wierzbowski, Warszawa 1907, s. 17. 
stworzyć w pełni uniwersytet. Jednocześnie cały czas dochodziło do zatargów między obu działającymi w Poznaniu szkołami - Akademią Lubrańskiego, funkcjonującą niedaleko Katedry jako kolonia akademicka Uniwersytetu w Krakowie, a tzw. Akademią Wielkopolską - spadkobiercą kolegium jezuickiego działającą tuż obok poznańskiego Rynku. Regularnie obie szkoły podbierały sobie uczniów, stosując mało wyszukane sposoby ich pozyskiwania, np. poprzez zapisy w trakcie semestru. Utrata ważnych stronników w osobach Augusta Sułkowskiego i Antoniego Ponińskiego znacznie osłabiła możliwości utworzenia uniwersytetu w Poznaniu, co więcej w łonie KEN pojawił się w 1778 r. pomysł złączenia obu szkół i przekształcenia ich w jedną szkołę wydziałową poznańską ${ }^{32}$. Negatywnie dla uniwersytetu w Poznaniu przysłużył się Hugo Kołłątaj, który skutecznie reformując Akademię Krakowską, zamienioną na Szkołę Główną, doprowadził do podporządkowania jej wszystkich innych szkół w Koronie. Jednocześnie jednak, nie bez wpływu na zdanie Kołłątaja o braku potrzeby stworzenia w Wielkopolsce nowej szkoły wyższej, pozostały jego związki personalne z Franciszkiem Minockim rektorem Akademii Lubrańskiego i przeciwnikiem Józefa Rogalińskiego. Ostateczna decyzja zapadła w KEN dnia 28 IV 1780 r., a rektorem nowo utworzonej Szkoły Wydziałowej w budynkach kolegium pojezuickiego został właśnie Franciszek Minocki ${ }^{33}$. Decyzja ta doprowadziła do „roztrwonienia” wyposażenia szkoły pojezuickiej, poprzez ich wywózkę np. instrumentów astronomicznych do Warszawy i Krakowa. Nowa szkoła przejęła uczniów obu szkół, a budynek Akademii Lubrańskiego przekazany został biskupowi poznańskiemu ${ }^{34}$.

Szkoła Wydziałowa Poznańska, funkcjonująca w latach 1781-1794, była już szkołą nowego typu, w której program nauczania wytyczony był każdorazowo przez KEN, a ewentualne modyfikacje były efektem nie tyle zarządzających szkołą, a wynikały jedynie z braku odpowiedniego nauczyciela przedmiotu czy ich indywidualnych predyspozycji, czemu zarówno szkoła, jak i KEN starały się zawsze dość szybko zaradzić. Trudno jednoznacznie ocenić poziom szkoły poznańskiej, jak i prześledzić znaczenie kształcenia szkolnego dla późniejszych karier uczniów. W pierwszym przypadku jest to wynik nie zawsze rozbudowanych ocen dokonywanych przez wizytatorów KEN, w drugim trudno dokonywać prostego przełożenia, iż to właśnie uczęszczanie do szkoły poznańskiej miało najważniejszy wpływ na kariery tych uczniów, którzy rzeczywiście późnej odgrywali bardziej znaczącą rolę w życiu politycznym państwa. O wiele ważniejsze były bowiem koneksje rodzin, z których pochodzili uczniowie, czy klientelizm. Szkoła Wydziałowa Poznańska, kierowana początkowo przez rektora Jana Paprockiego (1781-1784), a następnie

32 D. Żołądź-Strzelczyk, Szkoły w Wielkopolsce..., s. 197.

${ }^{33}$ Był on krótko rektorem poznańskim z uwagi na nowe zatargi z H. Kołłątajem - patrz K. Mrozowska, Funkcjonowanie systemu szkolnego..., s. 134.

${ }^{34}$ D. Żołądź-Strzelczyk, Szkoły w Wielkopolsce..., s. 198-200. 
Józefa Przyłuskiego (od 1785), stanęła od początku przed trudnym zadaniem odbudowania zaufania rodziców chcących posłać swoich synów do niej. Po kasacie szkolnictwa jezuitów, a następnie likwidacji obu Akademii i stworzenia nowej szkoły (rok szkolny 1781/1782), widać wyraźnie spadek liczby uczniów. Ponownie tendencję wzrostową można zauważyć dopiero począwszy od roku szkolnego 1786/1787, co wiązać należy nie tylko ze zmianami programów nauczania i odbudowania zaufania do szkoły, ale także okresem stabilności ekonomicznej i tym samym możliwości ponoszenia kosztów nauki przez rodziców uczniów. Analiza danych zebranych w oparciu o raporty dla KEN i sprawozdania rektorów szkoły poznańskiej przedstawionych częściowo w tabeli I, pozwala na sformułowanie kilku podstawowych wniosków:

1) Nie sprawdziły się założenia autorów (głównie KEN) połączenia i prostego (matematycznego) skupienia w niej wszystkich uczniów z obu szkół, nastąpił rzeczywisty odpływ uczniów. Samych uczniów Akademii Wielkopolskiej w latach 1780/81 było 207, danych z tego roku szkolnego Akademii Lubrańskiego brak, niemniej po powołaniu Szkoły Wydziałowej Poznańskiej liczba uczniów w kolejnym roku wynosiła zaledwie 141 i ponownie granicę 200 przekroczyła dopiero w latach 1791/1792. Pamiętać jednak należy, iż do 1780 r. klas było VII, co oczywiście wpływało na ogólną liczbę uczniów. Ewentualne różnice co do ilości uczniów w sprawozdaniach wynikały z różnej ich liczby w I i II semestrze i dość swobodnego opuszczania szkoły w trakcie roku ${ }^{35}$. Tym samym w raportach rektorów i wizytatorów bardzo często można dostrzec podniesioną liczbę uczniów - (największą w danym roku), podczas gdy w zestawieniu poszczególnych nauczycieli liczba ta jest zmienna i mniejsza. Jest to zabieg sprawozdawczy, który i teraz stosowany jest w szkolnictwie, co pokazuje niezmienność pewnych zachowań.

2) Uczniowie przychodzili do szkoły najczęściej w wieku 14/15 lat, a odchodzili w wieku lat 17. Najmłodsi przybywali w wieku 9 lat, a najstarsi w wieku lat 25. Wychodzili ze szkoły nie później niż w 26 roku życiu. Zaliczali najczęściej dwie-trzy klasy, z reguły klasę I i III, najrzadziej klasę VI (ew. wcześniej VII ${ }^{36}$ ), która akurat w programie zawierała głównie nauczanie prawa. Zaledwie niewielki procent uczniów (ok. 1-2\%) kończyło cały kurs sześcioletni. Podstawowe powody opuszczania szkoły przed końcem edukacji podzielić można na trzy grupy: koszty utrzymania (obejmujące stancję, wyżywienie, podręczniki, koszty opłacenia dyrektora - często pełnił tę funkcję uczeń ostatnich klas i był to sposób zarobkowania) ${ }^{37}$; brak przełożenia ukończenia całości kursu szkolnego na karierę zawodową wynikającą z braku prawnego obowiązku przedstawienia zaświadczenia ukończenia szkoły jako

35 Formalnie zajęcia w Szkole Wydziałowej trwały od końca września (początku października) do przełomu czerwca/lipca.

36 Przejście z systemu siedmioklasowego na sześcioklasowy wymuszony został przez KEN.

${ }^{37}$ Patrz szerzej K. Mrozowska, Funkcjonowanie systemu szkolnego..., s. 237, 245-249. 
wymogu objęcia stanowisk czy urzędów itp.; wiek uczniów - praktycznie rozpoczęcie kariery państwowej, względnie „handlowej” (odnośnie do mieszczan) możliwe było już od 17-18 roku życia, dlatego tylko bardzo wczesne rozpoczęcie nauki gwarantowało ukończenie całego kursu szkolnego przed osiągnięciem tego wieku, jednakże utrzymywanie ucznia tak długo i nieprzerwanie w szkole było dla rodziców bardzo kosztowne, a głównym celem oddawania synów do szkół było nauczanie ich podstaw wiedzy, a nie pogłębione kształcenie.

Tabela. 1 Zestawienie liczby uczniów Akademii Wielkopolskiej (z lat 1777-1781) i Szkoły Wydziałowej Poznańskiej (z lat 1781-1792) z podziałem na klasy (opracowanie własne).

\begin{tabular}{|c|c|c|c|c|c|c|c|c|}
\hline $\begin{array}{l}\text { Rok szkolny/ } \\
\text { /klasy }\end{array}$ & $\mathbf{I}$ & II & III & IV & $\mathbf{V}$ & VI & VII & Razem \\
\hline $1777 / 78$ & 25 & 24 & 24 & 26 & 9 & 7 & 22 & $137+4^{*}$ \\
\hline $1778 / 79$ & 22 & 23 & 35 & 6 & 5 & 6 & 29 & $126+10$ \\
\hline $1779 / 80$ & 33 & 37 & 29 & 14 & 17 & 10 & 20 & $160+8$ \\
\hline $1780 / 81$ & 56 & 28 & 64 & 11 & 16 & 16 & 16 & 207 \\
\hline $1781 / 82$ & 20 & 20 & 47 & 19 & 15 & 20 & & 141 \\
\hline $1782 / 83$ & 38 & 36 & 47 & 15 & 17 & 10 & & 163 \\
\hline $1783 / 84$ & 15 & 19 & 28 & 31 & b.d. & b.d. & & 93 (bez klasy V i VI) \\
\hline $1784 / 85$ & 32 & 12 & 33 & 14 & 17 & 11 & & 119 \\
\hline $1785 / 86$ & 21 & 24 & 19 & 12 & 13 & 8 & & 97 \\
\hline $1786 / 87$ & 29 & 34 & 34 & 13 & 17 & 9 & & 136 \\
\hline $1787 / 88$ & 43 & 23 & 31 & 14 & 15 & 5 & & 131 \\
\hline $1788 / 89$ & 34 & 35 & 32 & 15 & 21 & 6 & & 143 \\
\hline $1789 / 90$ & \multicolumn{7}{|c|}{ b.d. } & ok. 170 \\
\hline $1790 / 91$ & \multicolumn{7}{|c|}{ b.d. } & ok. 180 \\
\hline $1791 / 1792$ & \multicolumn{7}{|c|}{ b.d. } & ok. 212 \\
\hline
\end{tabular}

${ }^{*}$ W latach 1777-1780 funkcjonowała w Akademii Wielkopolskiej klasa teologiczna, ich stosunkowo niewielka liczba (w poszczególnych latach odpowiednio $4,10,8$ ) wynikała z funkcjonowania Akademii Lubrańskiego lepiej kształcącej w tym zakresie. Po powstaniu Szkoły Wydziałowej Poznańskiej klasa taka przestała istnieć.

3) Uczniowie pochodzili praktycznie z całej Polski, choć zdecydowanie przeważają uczniowie z Wielkopolski. Szczegółowe badania raportów wizy- 
tatorów KEN i sprawozdań szkolnych pozwalają na wskazanie następujących województw i ziem: poznańskie, pomorskie, kaliskie, gnieźnieńskie, sieradzkie, łęczyckie, sandomierskie, krakowskie, brzesko-kujawskie, wileńskie, mazowieckie, krakowskie, inowrocławskie, wołyńskie, rawskie, chełmińskie, Prusy ${ }^{38}$.

4) pochodzenie społeczne uczniów: $64 \%$ mieszczanie (np. Malcher Matuszewski z Buku - 161, I, 87; Józef Gulczyński z Kościana - 151, III-VI, 81-87); 32\% szlachta (np. Krzycki kasztelanic krzywicki, Raczyński pisarzewicz wschowski, Radzimski sędzic gnieźnieński, Jasieński łowczyc poznański, Chłapowski podsędkowicz poznański, Grabowski szambelanic); $2 \%$ chłopi; $2 \%$ brak jednoznacznej ,identyfikacji społecznej" 39 .

Programy szkolne, choć wydawałoby się, że w czasach funkcjonowania KEN były bardzo dobrze opracowane, w rzeczywistości jedynie wskazywały siatkę przedmiotów i ogólne wytyczne co do liczby godzin wykładów. Tym samym ich realizacja $\mathrm{w}$ poszczególnych szkołach odbiegała od siebie i wyglądała różnie nawet po wprowadzeniu struktury szkół wydziałowych w $1780 \mathrm{r}^{40}$ Dla celów porównawczych w trzech tabelach przedstawiona została struktura przedmiotów nauczanych w Akademii Wielkopolskiej i Szkole Wydziałowej Poznańskiej z podziałem na klasy (tabela II, III, IV). Zauważalna jest postępująca zmiana siatki przedmiotów, która w aspekcie nauczania prawa zmienia się korzystnie dopiero w II poł. lat 80. XVIII w. i to ewidentnie pod wpływem realizacji reform KEN i nadzoru Szkoły Głównej w Krakowie. Warte podkreślenia jest odejście od systemu nauczania wszystkich przedmiotów w poszczególnych klasach przez jednego nauczyciela na rzecz koncepcji specjalizacji wykładowców w poszczególnych przedmiotach i oderwania ich od „przynależności” do klas. Zestawienie przedmiotów w tabelach obejmujących trzy różne lata pozwala nie tylko na obrazowe ujęcie rodzajów przedmiotów wykładanych w szkołach poznańskich, ale i ukazanie skali nauczania przedmiotów prawniczych na tle innych oraz znikomej tak naprawdę liczby uczniów, którzy odbyli kursy z tych przedmiotów, oscylującej w całym analizowanym okresie średnio w roku szkolnym w granicach 10-20 osób. Podstawowy problem z nauczaniem przedmiotów prawniczych wynikał jednak nie tylko z niewielkiej liczby chętnych uczniów, ale z brakiem formalnego wymogu przedstawiania zaświadczenia o odbyciu takiego kursu prawniczego przy okazji starania się o miejsce np. w palestrze czy sądownictwie. Trudno tak-

${ }^{38}$ Niniejsze dane w oparciu o Raporty Szkoły Wydziałowej Poznańskiej składane Szkole Głównej Koronnej w latach 1777-1789, wyd. T. Wierzbowski, Warszawa 1905, s. 214-235.

39 Ibidem.

40 Przykładowo w raporcie F.S. Jezierskiego z 1785 r., w ramach uwag ogólnych tyczących się ogółu wizytowanych szkół wskazuje on na nieraz nieroztropne wybieranie autorów moralnych, potrzeba ksiażek elementarnych, duże zróżnicowanie w nauczaniu prawa politycznego i prawa natury w niektórych szkołach, mała znajomość wśród nauczycieli - Raporty generalnych wizytatorów z roku 1785, wyd. T. Wierzbowski, Warszawa 1914, s. 60. 
że mówić o dobrym przygotowaniu nauczycieli do wykładania przedmiotów prawniczych w ogóle w szkołach wydziałowych czy wcześniej w szkołach pojezuickich, skoro proces wymiany nauczycieli duchownych na świeckich rozpoczął się dopiero w latach 80 . XVIII w., a i kształcenie na uniwersytetach polskich w tym zakresie uznać należy za wysoce niewystarczające. Stąd też bardzo wiele zależało $\mathrm{w}$ praktyce od umiejętności i podejścia samych nauczycieli prawa oraz ich specjalizacji w tych przedmiotach. Wymogi KEN bowiem w zakresie nauczania odpowiednio np. prawa natury, prawa narodów czy przede wszystkim prawa krajowego pozostawały bardziej na papierze, brak bowiem było podręczników, jednolitości w skali krajowej wykładania tych przedmiotów odnośnie tak do treści, jak i sposobu. Tym samym w ramach wizytacji KEN czy Szkoły Głównej nie tylko poszczególni nauczyciele czy uczniowie uzyskiwali wyróżnienia i oceny, ale co ważne z wizytacji takich pochodziła informacja zwrotna, co do ewentualnych kierunków nauczania przedmiotów, w tym i prawniczych. $Z$ pewnością pożądanym stanem był więc taki, w którym nauczyciel prawa, po pierwsze, rzeczywiście posiadał odpowiednie wykształcenie, po drugie, specjalizował się wyłącznie w tych przedmiotach, co dawało mu szansę na rozwój, po trzecie realizował program nauczania z możliwością jego modyfikacji co do sposobu wykładu, tak aby był on jak najbardziej przydatny i rozwijający samych uczniów.

Materiał źródłowy pozwala na utworzenie wykazu nauczycieli wykładających prawo w Akademii Wielkopolskiej i Szkole Wydziałowej Poznańskiej ${ }^{41}$ w latach 1777-1792 (tabela V) ${ }^{42}$. Nauczyciele uczący prawa w Akademii Wielkopolskiej do $1780 \mathrm{r}$. wypadają zdecydowanie słabo, co z pewnością jest wynikiem braku specjalizacji w tym zakresie, a jednocześnie $\mathrm{z}$ racji prowadzenia lekcji z wszystkich przedmiotów w danej klasie z łatwością pomijania materii prawniczych na rzecz innych, na których profesorowie Akademii znali się lepiej. Już w 1775 r. szkoła poznańska wyraźnie zabiegała o przysłanie profesora prawa, czekając na decyzję w tej sprawie $\mathrm{KEN}^{43}$. W okresie funkcjonowania Akademii Wielkopolskiej jedynie nauczyciel świecki Jan Kanty Krusiński ${ }^{44}$ specjalizował się w prawie ekonomicznym, a pozostały przedmiotów prawniczych i nauki moralnej uczył raczej z musu, bardziej będąc

41 Patrz także Porzadek osób Zgromadzenia, [w:] Dzieje domowe albo opis przez dni osobliwszych dziejów i przypadków zdarzonych w Szkołach Wydziałowych Poznańskich 1781-1793, oprac. D. Żołądź-Strzelczyk, J. Wiesiołowski, Poznań 2006, s. 75-98.

${ }^{42}$ W oparciu o: Raporty Szkoty Wydziałowej... oraz Raporty wizytatorów... oraz Listy z prowincji... i Dzieje domowe...

${ }^{43}$ Raport Rogalińskiego „Potrzeba profesora praw świeckiego i medycyny” - Raporty generalnych wizytatorów..., s. 17.

${ }^{44}$ Był to drugi w tym czasie obok Nepomucena Tylkowskiego nauczyciel świecki w Szkole Wydziałowej Poznańskiej, próba laicyzacji szkoły poznańskiej na większą skalę rozpoczęła się dopiero w 1783 r. - por. K. Mrozowska, Walka o nauczycieli świeckich w dobie Komisji Edukacji Narodowej na terenie Korony, Wrocław 1956, s. 101-102. 


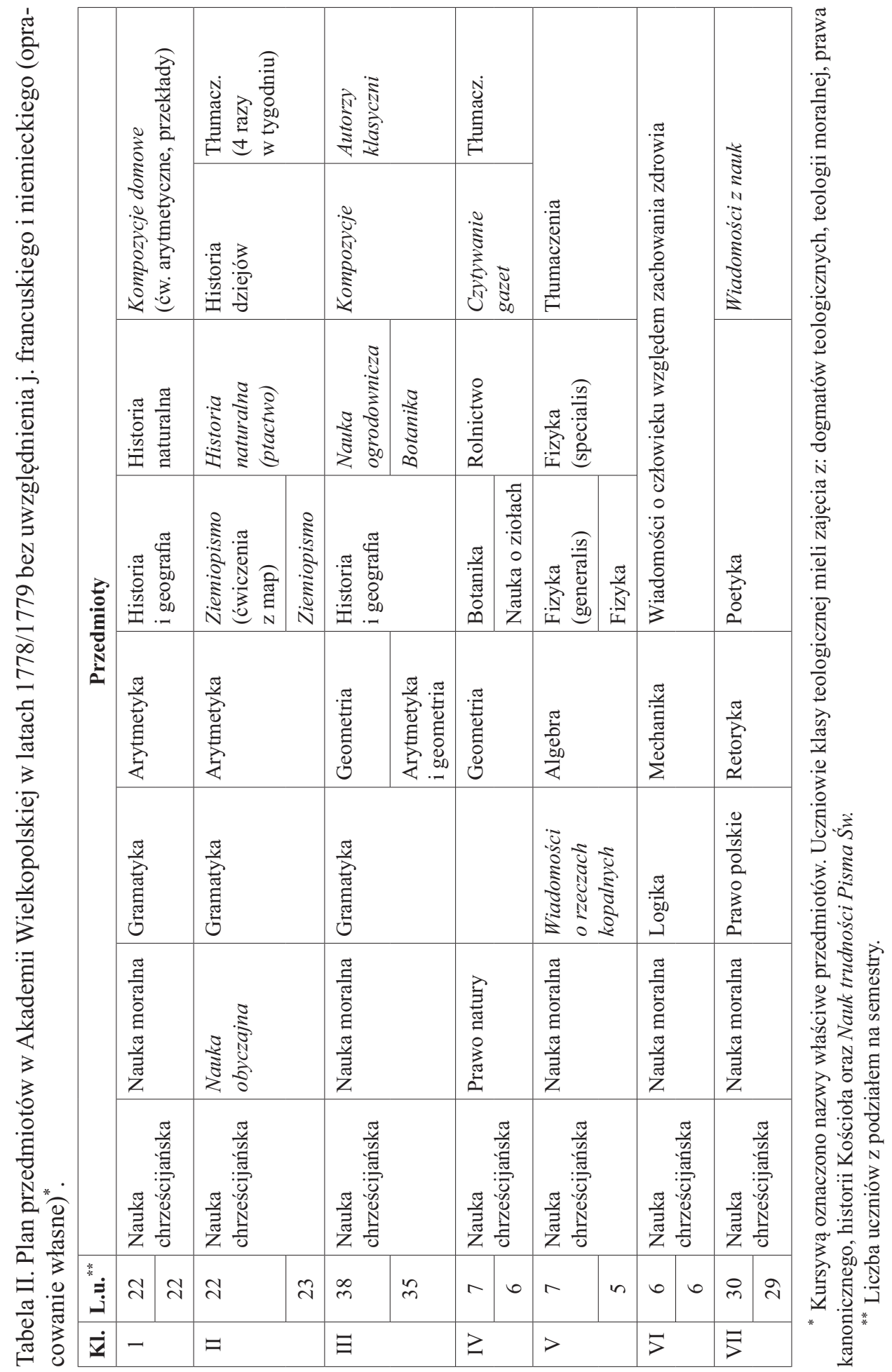




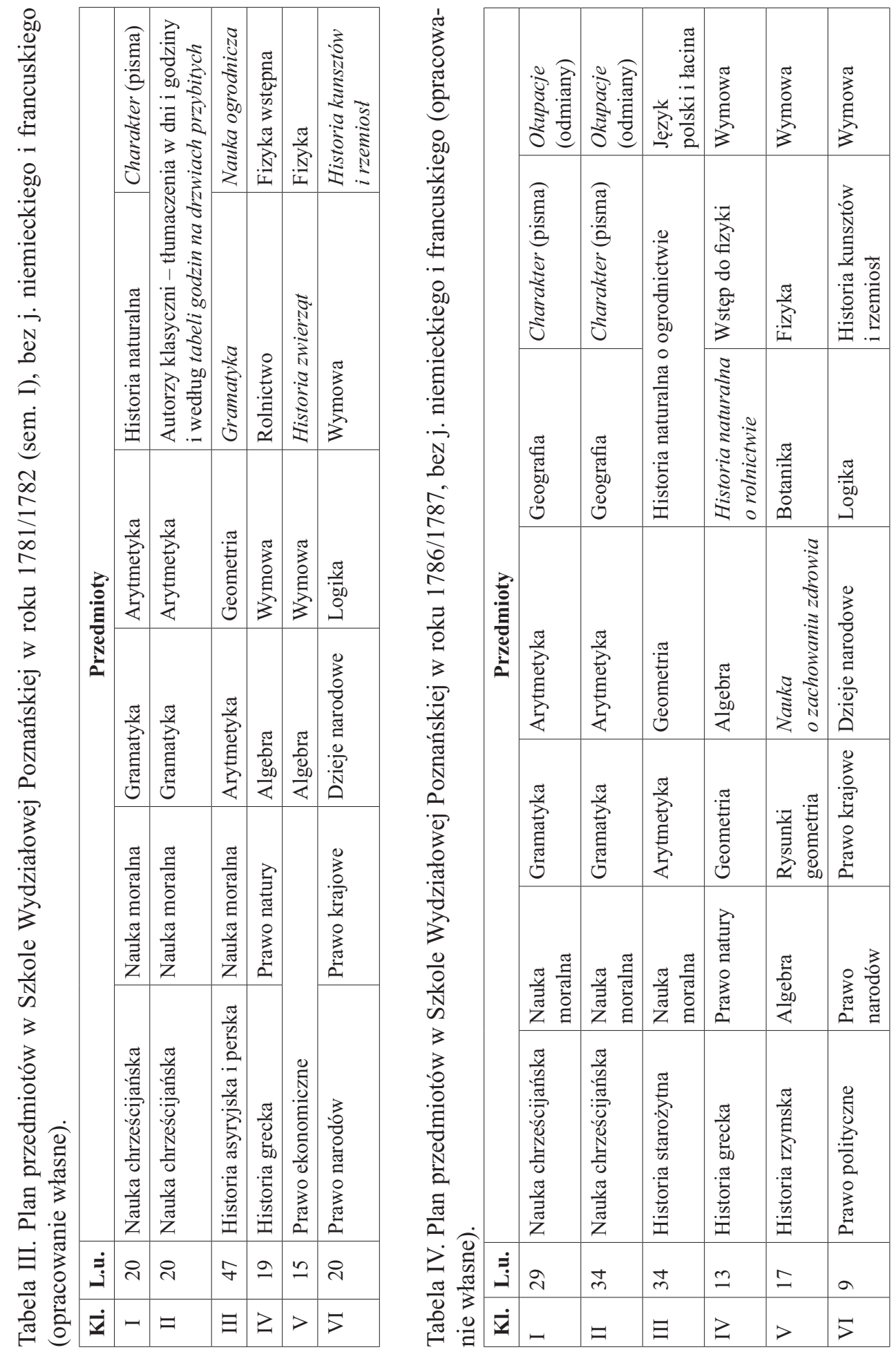


zainteresowany naukami ścisłymi. Od 1782 r. zastępował już w Szkole Głównej Feliksa Radwańskiego, będąc później wiceprofesorem w Kolegium Fizycznym (od 1787) i profesorem matematyki elementarnej (od 1790 r.). Odejście J.K. Krusińskiego oraz odsunięcie od wykładów ks. Ignacego Giecyego, zmusiło rektora Szkoły Wydziałowej Poznańskiej do przekazania wykładów z prawa osobie, która była na miejscu. Wybór padł na ks. Ignacego Oczykowskiego, wcześniej nauczającego w Akademii Lubrańskiego. Praktycznie nie znał się on na prawie ekonomicznym czy krajowym, dlatego też wbrew programowi prowadził zajęcia wyłącznie z nauki moralnej, historii (greckiej i rzymskiej) oraz prawa politycznego narodu polskiego. Wszystkie zajęcia opierały się na formule pytań, wypisów i tłumaczeń. Przykładowo w klasie V przewidywał przygotowanie uczniów z 25 pytań z historii rzymskiej, a w klasie VI w ramach prawa politycznego: „69 pytań z prawa stanów i państwa, $12 \mathrm{z}$ historii”" ${ }^{45}$. Niestety była to klęska dydaktyczna, którą potwierdziła wizytacja Bonifacego Garyckiego w 1783 r. W raporcie wskazano bowiem całą prawdę o nauczaniu przedmiotów prawniczych przez osobę do tego nie przygotowaną: „Nauczyciel prawa, układu ekonomicznego nie znający, na samych tylko wypisach cały rok strawił z uczniami, pożytek jednak z historii, którą dawał, jakikolwiek okazał się"46. Ta niska ocena spowodowała, iż Oczykowskiego postanowiono przenieść na stanowisko prefekta do Trzemeszna i szkoła ponownie szukała nauczyciela prawa. Ostatecznie dzięki Walerianowi Bogdanowiczowi udało się sprowadzić do Poznania od 1783 r. Mateusza Mecherzyńskiego, który starał się podnieść poziom nauczania przedmiotów prawniczych i co ciekawe zaczął zabiegać o zakup podręczników między innymi z nauki moralnej czy historii. Szczególnie dobrze znał Mecherzyński i tym samym w sposób usystematyzowany wykładał, prawo polityczne i prawo ekonomiczne (w trzech częściach: o reprodukcji, o narodowych podatkach, o konsumpcji $)^{47}$. W zakresie prawa krajowego Mecherzyński osobno traktował o politycznych i o cywilnych materiach, a wśród podręczników używał pracy Teodora Ostrowskiego z 1784 r. Generalnie jako nauczyciel przedmiotów prawniczych wprowadził sporo świeżości dydaktycznej, przede wszystkim poprzez wykorzystywanie lektur takich autorów, jak Hieronim Stroynowski czy Pierre Samuel du Pont de Nemours (do nauczania prawa politycznego $)^{48}$. Mecherzyński pozostał nauczycielem w Poznaniu zaledwie przez trzy lata, odchodząc do szkół winnickich. Od 1786 r. wykłady z prawa w Szkole Wydziałowej Poznańskiej realizuje Kazimierz Domaradzki (ur. 1756), który szkołę w Sandomierzu ukończył w 1781 r., mając aż 25 lat (!),

45 Patrz Raporty Szkoty Wydziałowej Poznańskiej..., s. 135.

46 Patrz: Raporty generalnych..., s. 8 oraz H. Pohoska, op. cit., s. 183.

47 Raporty Szkoty Wydziałowej Poznańskiej..., s. 149.

48 Por. Raporty Szkoty Wydziałowej Poznańskiej ..., s. 149-150. 


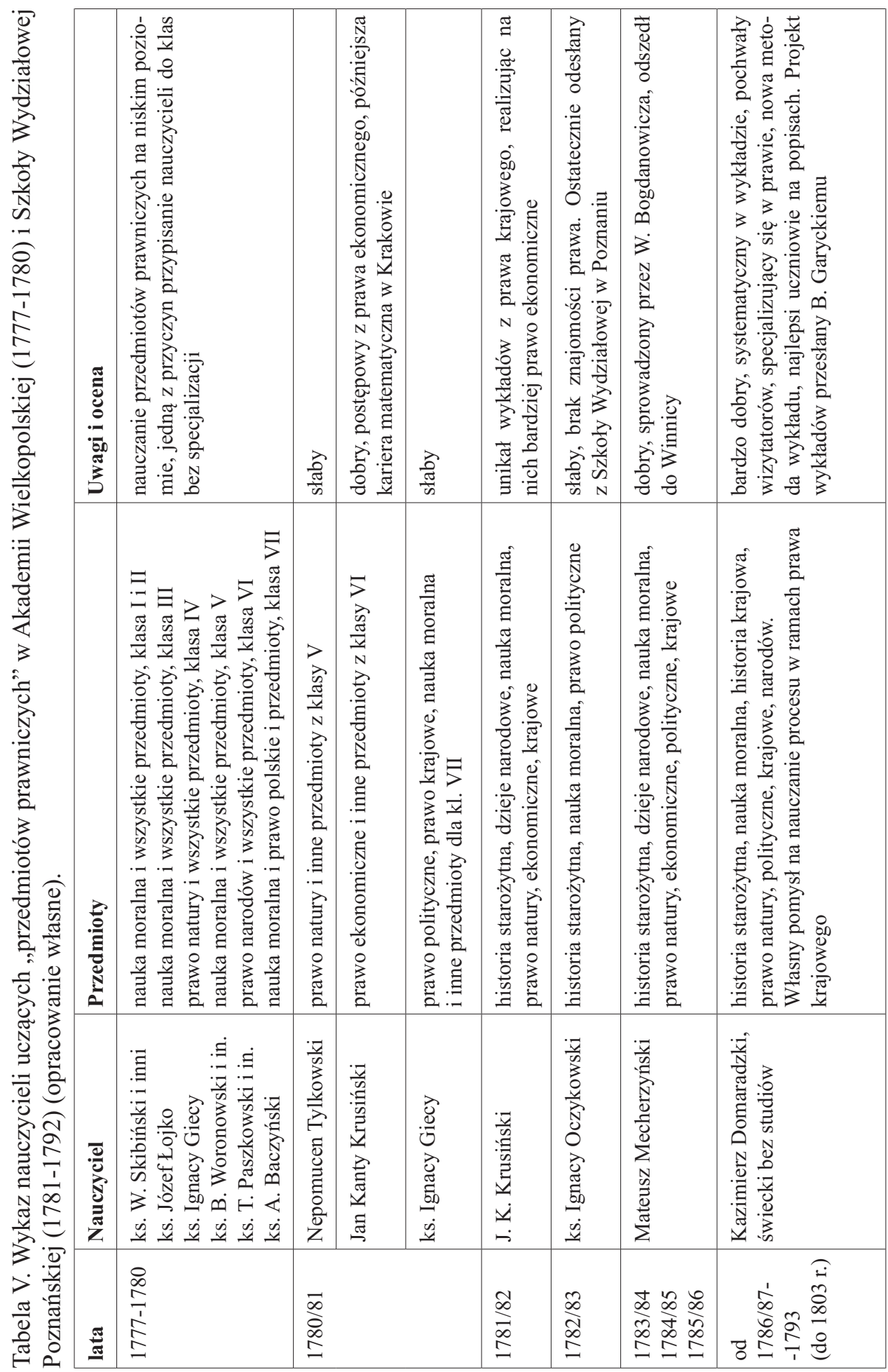


gdzie pozostał jako nauczyciel pierwszej klasy ${ }^{49}$. Nie miał jednak tam łatwego życia, zważywszy, iż był jednym z nielicznych w zgromadzeniu nauczycielem świeckim. Eksjezuita Józef Potoczyński próbował się pozbyć Domaradzkiego, o czym informował wizytator Franciszek Kolendowicz Hugona Kołłątaja już w 1783 r. Co ciekawe, Kazimierz Domaradzki był jednym z nielicznych nauczycieli, który wprost z ławy szkolnej przeszedł na katedrę, a w późniejszym czasie uzyskiwał lepsze noty od wizytatorów niż jego koledzy kształceni w Szkole Głównej ${ }^{50}$. Począwszy od 1784 r. Domardzki postanowił specjalizować się w prawie ${ }^{51}$, a w 1784 uzyskał doktorat z nauk wyzwolonych i już jako profesor prawa przeniesiony został do Łęczycy, gdzie wykładał zaledwie jeden rok. Kontakty utrzymywał tam właściwie jedynie $\mathrm{z}$ innym nauczycielem świeckim Jakubem Chodackim ${ }^{52}$. Za przeniesieniem do Poznania Domaradzkiego stał Walerian Bogdanowicz, który postanowił wstawić się w Szkole Głównej za profesorem prawa ${ }^{53}$, chcącym przenieść się do większego ośrodka. W liście polecającym Jana Śniadeckiego do rektora Przyłuskiego opisany został charakter nowego nauczyciela: „Człowiek dobry, spokojny, ale trochę w mówieniu prędki - należy do mnie W.P. D. [Domaradzkiego - W.Sz.] uprzedzić o tej wadzie, która go zapewne wiele już przykrości kosztuje i mam mocną nadzieję, że się po odebranym teraz napomnieniu poprawi, do czego jeszcze gdy w nadarzonej potrzebie przyłoży się W.P.D. swymi zwykłymi pełnymi łagodności refleksjami, nie wątpię, że będziesz bardzo kontent $\mathrm{z}$ tego nauczyciela" 54 . Już w początkach swojej kariery dydaktycznej poznał się Domaradzki w Poznaniu z dobrej strony, czego dowodem mogą być nie tylko raporty wizytatorów wysoko oceniających uczniów z przedmiotów, które on prowadził w klasach $\mathrm{IV}-\mathrm{VI}^{55}$, ale także indywidualne

49 K. Domaradzki został nauczycielem zaraz po ukończeniu szkoły, inaczej więc niż zakładał pierwotnie projekt H. Kołłątaja odnośnie do kształcenia nauczycieli świeckich. W 1780 r. zreformowano Seminarium Kandydatów Stanu Nauczycielskiego w Krakowie (pod nadzorem m.in. Antoniego Popławskiego, Bonifacego Garyckiego i Hieronima Stroynowskiego), w którym mieli się kształcić przyszli nauczyciele, dobierani spośród uboższej szlachty, po ukończeniu przez nich pełnego kursu szkoły wydziałowej - patrz J. Berger-Mayerowa, Nieznane zarzadzenie Hugona Kollataja Rektora Krakowskiej Szkoły Głównej Koronnej z 19 lipca 1783 r., Wrocław 1965, s. 5-7.

50 K. Mrozowska, Funkcjonowanie systemu szkolnego..., s. 159.

51 Jednakże dopiero od 1786 r. informował Domaradzki swoich przełożonych o chęci specjalizowania się w prawie. Patrz list K. Domaradzkiego do sekretarza Szkoły Głównej z 28 III 1786 r.: „Uczę tu [w Łęczycy - W.Sz.] wymowy i prawa. Lecz byłbym na zawsze chciał się chwycić prawa jako zgadzającego się z upodobaniem moim” - Archiwum UJ rkps 274, 1. 70.

52 Wykładającym później w Poznaniu w latach 1788-1793.

53 Patrz listy W. Bogdanowicza do sekretarza Szkoły Głównej z 23 V 1786 r. i 5 VIII 1786 r. Listy z prowincji. Korespondencja wizytatorów generalnych, rektorów i nauczycieli z Szkołą Główna Koronna 1779-1794, oprac. K. Mrozowska, Warszawa 1998, s. 35 i 40.

54 Cyt. za K. Mrozowska, Walka o nauczycieli..., s. 105-106.

55 Księga zdań o postępkach uczniów toż egzaminów odprawionych i zapisanych, [w:] Dzieje domowe albo opis przez dni osobliwszych..., s. 109-113. 
oceny samego nauczyciela. W 1787 r. Bonifacy Garycki ${ }^{56}$ jako wizytator szkół chwalił generalnie stan wszystkich nauk oprócz wymowy, wskazując, iż „z prawa atoli największą uczniowie odnieśli korzyść”, a Domaradzki zasłużył „na zaletę u P. Komisji” ${ }^{57}$. Był też nauczycielem docenianym przez swoich kolegów, czego dowodem może być przyznanie jemu, już po roku bytności w Poznaniu, wykładu inauguracyjnego - „na otwarcie nowego roku nauki 7 X 1787 r. mowę miał w języku polskim Kazimierz Domaradzki, profesor prawa, w stylu gładkim ułożona, wystawiała przyrodzony porządek ludzkich społeczeństw"58. Kolejni wizytatorzy w osobach Kazimierza Gołeckiego i Józefa Przyłuskiego w raportach do Szkoły Głównej także chwalili Domaradzkiego: z jasnego i pracowitego tlumaczenia się, tudzież z znakomitej uczniów korzyści $i^{59}$. Domaradzki cały czas uczył się i opracowywał własne wykłady w Poznaniu, korzystając np. w zakresie prawa kanonicznego z konsultacji z ks. Jerzym Chudzickim ${ }^{60}$, który w pewnym momencie w ogóle nie miał żadnej klasy w szkole $\mathrm{z}$ racji braku zainteresowanych uczniów ${ }^{61}$. Całościowy wykład z prawa musiał w formie pisemnej opracować Domaradzki jeszcze przed połową $1790 \mathrm{r}$. i był on zapewne dość oryginalny, zważywszy na fakt, iż przesłany został przez Józefa Przyłuskiego do sekretarza Szkoły Głównej w Krakowie celem przekazania go Bonifacemu Garyckiemu ${ }^{62}$. Niestety, opracowania Domaradzkiego nie udało się odszukać, także w papierach Bonifacego Garyckiego, tym samym trudno jednoznacznie ocenić ich zawartość merytoryczną. W okrojonym zakresie można je próbować tylko odtworzyć w oparciu o sprawozdania profesora prawa z wykładów z poszczególnych przedmiotów, które jednak mają inny charakter niż systematycznie poprowadzony wykład z poszczególnych przedmiotów prawniczych. Zapewne Domaradzki przesłał Garyckiemu swoje wykłady, ponieważ już w trakcie wizytacji zwrócił on uwagę Garyckiego, także jeżeli chodzi o sposób jego prowadzenia. Co ciekawe zawsze dostrzegali to wizytatorzy - jeden z nich - J.K. Krusiński (były nauczyciel w tej szkole) w swoim raporcie z 1792 r. zawarł specjalną ich ocenę: „Egzamin z prawa najmocniejsze w wizytatorze wzbudził ukontentowanie. Sposób uczenia profesora jest wcale osobliwy. Nie dyktuje

56 Odnośnie do postaci B. Garyckiego patrz J. Sondel, Bonifacy Garycki (1742-1822), [w:] Uniwersytet Jagielloński. Złota Księa Wydziału Prawa i Administracji, pod red. J. Stelmacha i W. Uruszczaka, Kraków 2000, s. 107-111.

${ }^{57}$ Raporty Szkoty Glównej..., s. 16.

58 Dzieje domowe albo opis przez dni osobliwszych dziejów..., s. 54.

${ }^{59}$ Patrz list J. Przyłuskiego do Szkoły Głównej z 7 I 1791 r. - Listy z prowincji..., s. 240.

${ }^{60}$ K. Mrozowska, Funkcjonowanie systemu szkolnego..., s. 163.

${ }^{61}$ Patrz raport z 1791 r. dla Szkoły Głównej - Raporty Szkoły Głównej Koronnej o generalnych wizytach szkół Komisji Edukacji Narodowej 1787-1793, oprac. K. Mrozowska, Wrocław-Warszawa-Kraków-Gdańsk-Łódź 1981, s. 183-184.

${ }^{62}$ Patrz list J. Przyłuskiego do sekretarza Szkoły Głównej z 2 VIII 1790 r. - Listy z prowincji..., s. 237. 
on seksternów, ale tylko materie do obiektu swego należące tłumaczy, uczniowie dopiero na wytłumaczone sobie w szkole materie w domu przygotowują odpisy, musi to być skutkiem dobrego i jasnego thumaczenia się profesora, kiedy uczniowie przynosząc przez siebie wygotowane odpisy, różnią się w słowach, ale mało $\mathrm{w}$ myślach i ich z sobą powiązaniu, każdy tedy uczeń w materiach prawa natury, ekonomicznego, politycznego ma przez siebie w domu ułożony sekstern i z niego się tłomaczy. Te seksterny wizytator przeglądał i o rzeczywistości przekonał się. Szkoła Główna ma honor polecić profesora tego szczególnym P. Komisji względom"63. Na szczególną uwagę zasługuje także wprowadzenie do wykładu z prawa krajowego nauki z procesu sądowego, elementu bardzo praktycznego, ale rzadko wykładanego w szkole uczniom.

Jak bardzo odbiegał program nauczania i jego realizacja w zależności nie tylko od wymogów ogólnych, ale i pracy samych nauczycieli, ukazuje zestawienie przedmiotów należących $\mathrm{w}$ rozumieniu ówczesnych do przedmiotów prawniczych w Akademii Wielkopolskiej w latach 1777-1778 i w szkole Wydziałowej Poznańskiej w latach 1786/1787, gdy wykładowcą był Kazimierz Domaradzki (tabele VI i VII). W Akademii Wielkopolskiej ,wykłady prawnicze", za wyjątkiem nauki moralnej, były prowadzone w sposób mało usystematyzowany i ubogi w treści. Uczniowie uzyskiwali wiedzę ,przestarzałą”, a sposób wykładu w postaci odczytywania fragmentów dzieł przez nauczycieli duchownych pozostawiał wiele do życzenia. Tym samym w pełni zasadne jest uznanie działań KEN odnośnie do wprowadzania do szkolnictwa nauczycieli świeckich, najczęściej nowych, młodych i studiujących wcześniej na uniwersytetach. W Szkole Wydziałowej Poznańskiej o początku procesu podnoszenia poziomu nauczania prawa można mówić nie wraz z wprowadzeniem nowych programów nauczania przez KEN, ale wraz z zatrudnieniem przygotowanych do wykładów z przedmiotów prawniczych nauczycieli świeckich, najpierw Mateusza Mecherzyńskiego, a następnie Kazimierza Domaradzkiego. Pewien paradoks polega na tym, iż liczba uczniów ostatniej „klasy prawniczej” była ciągle niższa za kadencji tych nauczycieli niż w czasach wcześniejszych, podczas gdy poziom nauczania był nieporównywalnie wyższy. Mecherzyński prawo natury wykładał w klasie IV, omawiając w kolejności: potrzeby człowieka, prawa, czyli należytości i powinności, własność ruchoma $i$ stany przyrodzone ${ }^{64}$. W klasie $\mathrm{V}$ wykładał prawo ekonomiczne i prawo polityczne (m.in. o związu pospolitym, o zwierzchności, o narodzie prawej zwierzchności podległym ${ }^{65}$, a w VI prawo krajowe, dzieje narodowe (opierając się na T. Wadze i A. Naruszewiczu) i prawo narodów (dwie części: należytości i powinności powszechne, o handlu i sprawiedliwości między na-

63 Patrz Raporty Szkoty Gtównej Koronnej o generalnych wizytach..., s. 193.

${ }^{64}$ Raporty Szkoly Wydziałowej Poznańskiej..., s. 149.

65 Ibidem. 
rodami opierając się m.in. na pracach Emericha de Vattela $\left.{ }^{66}\right)$. Gdy doda się do przerabianej przez uczniów wyżej wskazywanej literatury tj. T. Ostrowskiego, Du Ponta, J. Skrzetuskiego, to dostrzegalna jest próba Mecherzyńskiego wprowadzania uczniów w pisma autorów współczesnych, a przede wszystkim realizacji bardziej oświeceniowego (w duchu KEN) programu nauczania. Z pewnością jednak dopiero przybycie do Poznania Kazimierza Domaradzkiego dawało uczniom szansę na wykłady jeszcze bardziej usystematyzowane, a przede wszystkim na jeszcze wyższym poziomie szczególnie z jednego przedmiotu, dotąd dość zaniedbywanego, tj. prawa krajowego. Zważywszy na fakt, iż praktycznie do wszystkich przedmiotów prawniczych wykładanych wtedy w Szkole Wydziałowej Poznańskiej brak było oficjalnych podręczników, przygotowanie autorskich wykładów uwzględniających zalecenia KEN czy Szkoły Głównej było sporym wyzwaniem dla nauczyciela. Przykładowo Domaradzki ciekawie prowadził wykłady już w klasie III, łącząc lekcje historii z geografią ${ }^{67}$. Wprowadził także obowiązek czytania przez uczniów „Dziennika Handlowego” jako sposobu dodatkowego rozbudzania zainteresowania uczniów sprawami gospodarczymi ${ }^{68}$. Między wykładami prowadzonymi przez Domaradzkiego w poszczególnych klasach widać uporządkowanie materii, na tyle duże, iż z pewnością rzadko zdarzały się powtórzenia, co wcześniej szczególnie na lekcjach prowadzonych jeszcze w Akademii Wielkopolskiej było powszechną praktyką. Po drugie, wprowadzenie w ramach prawa krajowego nauczania procesu z wszystkimi akcesoriami z omówieniem terminów łacińskich używanych w dekretach i akcesoriach oraz nauczanie aspektów egzekucyjnych musi budzić uznanie dla Domaradzkiego ${ }^{69}$. Po trzecie, sposób nauczania musiał być skuteczny, skoro uczniowie przyswajali sobie dobrze materię i uzyskiwali wysokie noty u wizytatorów.

Wielu uczniów, zarówno Akademii Lubrańskiego, jak i Kolegium pojezuickiego (Akademii Wielkopolskiej), czy samej Szkoły Wydziałowej Poznańskiej „uciekało” do palestry i sądownictwa zaledwie po roku czy dwóch latach nauki, nie wynosząc z tych szkół absolutnie żadnej znajomości prawa, a i bardzo słabą znajomość czytania i pisania po łacinie, przydatną cały czas w praktyce wymiaru sprawiedliwości w Polsce. Tym samym ze strony środowiska nasilały się krytyczne oceny szkolnictwa jako miejsca kształcenia i jego przydatności dla kariery prawniczej. Dowodem na to może być fragment raportu Bonifacego Garyckiego jako wizytatora szkół z 1783 r.: „Co mają czynić z tymi uczniami, którzy nie umiejąc po łacinie z I i II klasy

${ }^{66}$ Ibidem, s. 150.

${ }^{67}$ Ibidem, s. 186.

68 Ibidem, s. 194. Odnośnie do znaczenia „Dziennika Handlowego” patrz E. Danowska, Dziennik Handlowy (1786-1793) w świetle literatury przedmiotowej, „Rocznik Historii Prasy Polskiej” 2009, t. XII, z. 2, s. 89-106.

${ }^{69}$ Ibidem, s. 194. 
Tabela VI. Program (treści) ,przedmiotów prawniczych” realizowanych w Akademii Wielkopolskiej w 1777/1778 (opracowanie własne).

\begin{tabular}{|c|c|c|}
\hline $\begin{array}{l}\text { Klasa, przedmiot, } \\
\text { liczba uczniów } \\
\text { w semestrze }\end{array}$ & \multicolumn{2}{|c|}{ Opis, książki, metoda i inne } \\
\hline \multicolumn{3}{|c|}{ Klasa I - 25 uczniów, 24 uczniów } \\
\hline Nauka moralna & O powinnościach dzieci ku rodzicom & Wypisy KEN na klasę I \\
\hline \multicolumn{3}{|c|}{ Klasa II - 24 uczniów, 26} \\
\hline Nauka moralna & $\begin{array}{l}\text { O powinnościach wzajemnych między } \\
\text { uczniem a nauczycielem }\end{array}$ & Wypis KEN na klasę II \\
\hline \multicolumn{3}{|c|}{ Klasa III - 24 uczniów, 25 uczniów } \\
\hline Nauka moralna & \multicolumn{2}{|c|}{$\begin{array}{l}\text { O obyczajności i uczciwości ludzkiej (jak do zwyczaju narodu się stosować, } \\
\text { jak postępować względem ludzi) }\end{array}$} \\
\hline \multicolumn{3}{|c|}{ Klasa IV - 26 uczniów, 20 uczniów } \\
\hline Prawo natury & \multicolumn{2}{|c|}{$\begin{array}{l}\text { Sem. I: a) O prawie natury w powszechności (jak fundament i prawidło praw } \\
\text { wszystkich), b) Prawo natury jako zasadzajace się na bytności Boga. } \\
\text { Sem. II: O obowiązkach względem Boga i bliźnich }\end{array}$} \\
\hline \multicolumn{3}{|c|}{ Klasa V-9 uczniów, 7 uczniów } \\
\hline Nauka moralna & \multicolumn{2}{|c|}{$\begin{array}{l}\text { Sem. I: Wyrastajaca z prawa politycznego, o polityce jako rządzeniu pań- } \\
\text { stwem sprawiedliwie i madrze, o naturze państw i ksztaltach rzadu, o przy- } \\
\text { czynach upadku państw. Sem. II: Panowanie niewiast, o religii i prawach }\end{array}$} \\
\hline \multicolumn{3}{|c|}{ Klasa VI - 7 uczniów, 8 uczniów } \\
\hline Prawo narodów & \multicolumn{2}{|c|}{$\begin{array}{l}\text { Sem. I: Odróżnienie prawa narodów od prawa natury }+ \text { o poselstwach } \\
\text { wszelkie wiadomości. } \\
\text { Sem. II: W wojnie i wojnie sprawiedliwej i niesprawiedliwej } \\
\text { Wykorzystywane książki: J.F. Finetti, De principiis iuris naturae et gentium } \\
\text { (t. I-II), 1777; S. Puffendorf, De iura naturae et gentium libri VIII, 1672; } \\
\text { A. Zeplichal, De iuris naturalis prudentia, } 1772 \text {. }\end{array}$} \\
\hline \multicolumn{3}{|c|}{ Klasa VII - 22 uczniów, 20 uczniów } \\
\hline $\begin{array}{l}\text { Nauka moralna } \\
\text { w sem. I } \\
\text { Prawo polskie } \\
\text { w sem. II }\end{array}$ & $\begin{array}{l}\text { Zasadzona na wiadomościach prawa } \\
\text { polskiego, o obszerności i rozmaitości } \\
\text { praw polskich } \\
\text { O sposobie rzadu polskiego, o interre- } \\
\text { gnum, o sejmie konwokacyjnym }\end{array}$ & $\begin{array}{l}\text { Dyktowane, thumaczone i powta- } \\
\text { rzane w oparciu o pracę G. Len- } \\
\text { gnicha. }\end{array}$ \\
\hline
\end{tabular}


Tabela VII. Program realizowany w 1786/1787 przez nauczyciela prawa Kazimierza Domaradzkiego w Szkole Wydziałowej Poznańskiej (opracowanie własne).

\begin{tabular}{|c|c|c|c|}
\hline $\begin{array}{l}\text { Klasa, } \\
\text { liczba uczniów, } \\
\text { przedmioty }\end{array}$ & Opis & $\begin{array}{l}\text { Książki } \\
\text { i pomoce naukowe }\end{array}$ & Metoda $\mathrm{i}$ inne \\
\hline \multicolumn{4}{|l|}{ Klasa III - 34 uczniów } \\
\hline Nauka moralna & $\begin{array}{l}\text { Cnoty i wady człowieka- } \\
\text { z klasycznych autorów opa- } \\
\text { trzone ocenami moralnymi }\end{array}$ & Brak informacji & $\begin{array}{l}\text { Wybór autorów } \\
\text { dokonywany przez } \\
\text { uczniów na piśmie } \\
\text { (po polsku i łacinie), } \\
\text { odtwarzany } \\
\text { z pamięci }\end{array}$ \\
\hline Historia starożytna & $\begin{array}{l}\text { Geografia narodów na } \\
\text { świecie, powstanie i upadek } \\
\text { państw }\end{array}$ & $\begin{array}{l}\text { Książka elementarna } \\
\text { z historii }\end{array}$ & Łacina \\
\hline \multicolumn{4}{|l|}{ Klasa IV - 13 uczniów } \\
\hline Prawo natury & \multicolumn{2}{|c|}{$\begin{array}{l}\text { 1) natura człowieka - o potrzebach, o związkach } \\
\text { potrzeb człowieka z rzeczami i społeczeństwem } \\
\text { 2) prawa osoby człowieka - należytości, powinno- } \\
\text { ści człowieka, prawa człowieka samotnego i sto- } \\
\text { warzyszonego } \\
\text { 3) prawa pracy człowieka - stopnie pracy czło- } \\
\text { wieka, prawo własności ruchomej i nieruchomej, } \\
\text { prawo umów pracy, prawo wolnej zamiany rzeczy } \\
\text { zdobytej pracą }\end{array}$} & $\begin{array}{l}\text { Wykład ustny, } \\
\text { uczniowie przygoto- } \\
\text { wywali samodziel- } \\
\text { nie odpisy (w domu } \\
\text { i przynosili celem } \\
\text { oceny) }\end{array}$ \\
\hline Historia grecka & $\begin{array}{l}\text { Ustrój grecki, dobre i złe } \\
\text { prawa, edukacja, cnoty } \\
i \text { wystepki, przyczyny } \\
\text { upadku }\end{array}$ & \multicolumn{2}{|c|}{$\begin{array}{l}\text { Książka elementarna do dziejów greckich } \\
+ \text { Cyceron i Plutarch }\end{array}$} \\
\hline Klasa V - 17 uczniów & $\begin{array}{l}\text { W klasie V w roku szkol- } \\
\text { nym 1787/88 zamiast } \\
\text { historii rzymskiej wykładał } \\
\text { Domaradzki - prawo } \\
\text { ekonomiczne w duchu } \\
\text { fizjokratyzmu }\end{array}$ & \multicolumn{2}{|c|}{$\begin{array}{l}\text { o reprodukcji jak się wprowadza } \\
\text { i utrzymuje, potem o cyrkulacji } \\
\text { i konsumpcji }\end{array}$} \\
\hline Historia rzymska & $\begin{array}{l}\text { Części historii Rzymu } \\
\text { zakończone na a) wypę- } \\
\text { dzeniu królów, b) wojnach } \\
\text { punickich, c) upadku rządu } \\
\text { republikańskiego. Także } \\
\text { o sądach, karach i obrząd- } \\
\text { kach rzymskich }\end{array}$ & $\begin{array}{l}\text { Dykcjonarz } \\
\text { starożytności }+ \\
\text { prace Liwiusza, } \\
\text { Eutropiusza }\end{array}$ & $\begin{array}{l}\text { Historii tej nabywali } \\
\text { ze stuchania potem } \\
\text { przynosili uczniowie } \\
\text { swoim stylem odpisy }\end{array}$ \\
\hline
\end{tabular}


Tabela VII. cd.

\begin{tabular}{|c|c|c|}
\hline $\begin{array}{l}\text { Klasa, } \\
\text { liczba uczniów, } \\
\text { przedmioty }\end{array}$ & $\begin{array}{c}\text { Książki } \\
\text { i pomoce naukowe }\end{array}$ & Metoda i inne \\
\hline \multicolumn{3}{|c|}{ Klasa VI - 9 uczniów } \\
\hline Prawo polityczne & $\begin{array}{l}\text { 1) początek spoleczeństwa-stany rolnicze, umowy } \\
\text { podlegajace kontroli zwierzchności } \\
\text { 2) powinności rzadu-utrzymywanie spokoju, czy- } \\
\text { nienie nakładów, o potrzebie w kraju: prawa, ma- } \\
\text { gistratur, edukacji i wojska } \\
\text { 3) należytości rzadowi-podległość narodu, wybie- } \\
\text { ranie podatków, przyzwoita nagroda }\end{array}$ & \multirow{2}{*}{$\begin{array}{l}\text { Praw uczniowie na- } \\
\text { bywali z stuchania, } \\
\text { a potem przynosili } \\
\text { na podania swoje } \\
\text { odpisy. } \\
\text { W spisie z lipca } \\
1789 \text { r. Domaradzki } \\
\text { wskazuje, iż czytali } \\
\text { „Dziennik Handlo- } \\
\text { wy”. }\end{array}$} \\
\hline Prawo narodów & $\begin{array}{l}\text { 1) stan naturalny narodów - naturalne obowiązk } \\
\text { narodów } \\
\text { 2) stan handlu między narodami - o korzyściach } \\
\text { z wolności handlu } \\
\text { 3) stan pokoju i wojny - przymierza narodów, przy- } \\
\text { czyny wojen, prawo wojny }\end{array}$ & \\
\hline Prawo krajowe & $\begin{array}{l}\text { o źródłach prawa polskiego, o rządzie, prawach } \\
\text { kardynalnych, prawach status, o królu, o senacie, } \\
\text { o stanie rycerskim, sejmach, sejmikach, Radzie } \\
\text { Nieustającej, skarbie, wojsku, sądach sejmowych, } \\
\text { relacyjnych trybunalskich, marszałkowskich, ase- } \\
\text { sorskich, skarbowych, referendarskich, podkomor- } \\
\text { skich, ziemskich, grodzkich pogranicznych. Dodat- } \\
\text { kowo byt tlumaczony proces w kraju praktykowany } \\
\text { z wszystkimi akcesoriami z wyłożeniem terminów } \\
\text { tacińskich w dekretach akcesoryi używanych, zapo- } \\
\text { wiedzeniem sposobów i praw stużacych egzekucji } \\
\text { dekretów. }\end{array}$ & \\
\hline Historia krajowa & $\begin{array}{l}\text { Poczatek historii od geografi - granice kraju, po- } \\
\text { działy polityczne itd. Podział historii na: poczatki } \\
\text { kraju i jego dzieje niepewne; Piastowie; Jagiello- } \\
\text { nowie, czasy wolnej elekcji }\end{array}$ & \\
\hline
\end{tabular}

idą do palestry? Skąd ohyda szkół i narzekania na teraźniejszą edukację"70. $\mathrm{Z}$ drugiej jednak strony należy pamiętać o micie kształcenia praktycznego, realizowanego jakoby w kancelariach. Rzeczywistej nauki tam nie było, ponieważ w przeważających przypadkach młodzież pozostawała tam bez opieki i brakowało zorganizowanego systemu nauczania, choć projekty takie przy okazji reformy, choćby adwokatury i sądownictwa, pojawiały się często

${ }^{70}$ Raporty Generalnych Wizytatorów z r. 1783..., s. 37. 
w czasach stanisławowskich ${ }^{71}$. Praktyka prawnicza stanowiła wycinek nie pozwalający dostrzec przez młodzież systemu funkcjonowania prawa, ani nawet stworzyć wyobrażenia związków prawa i ich właściwego usystematyzowania. Bardzo często praktycy sami nie znali dobrze prawa, trudno więc, by go skutecznie uczyli. Zważywszy dodatkowo na fakt, iż co do zasady sędziowie byli gorzej wykształceni od adwokatów (co było nieraz przyczyną tzw. buntów palestry ${ }^{72}$ ), a wykształcenie prawnicze nie było warunkiem sine qua non do objęcia urzędu sędziego, to stan taki wspierał powszechne przekonanie o większym znaczeniu roli „nieskalanego charakteru” i „czuciu prawa” niż jego znajomości przy karierze sądowniczej. Mit praktycznego nauczania prawa był silnie powiązany z przekonaniem, iż praktyka zdecydowanie lepiej niż szkolnictwo przygotowuje do pełnienia urzędów (także sądowych). W rzeczywistości palestranci szukali protektorów, a mecenasi czy urzędnicy sądowi nie byli zainteresowani uczeniem czegokolwiek, nie posiadając często takich umiejętności.

Ustanowienie Szkoły Wydziałowej Poznańskiej było krokiem w właściwym kierunku zważywszy na budowanie jednolitości programowej szkolnictwa średniego w Polsce. Na tle innych szkół wydziałowych, szkoła poznańska odnośnie do nauczania prawa stała na wysokim poziomie, szczególnie od momentu, gdy nastąpiły zmiany i przedmioty prawnicze zaczęli wykładać nauczyciele świeccy, jak choćby Mateusz Mecherzyński czy Kazimierz Domaradzki. Chociaż KEN i Szkoła Główna dość szybko reagowały (poprzez swoich wizytatorów) na nieprawidłowości i poziom nauczania, to jednak zdecydowanie najwięcej zależało od samych nauczycieli, którzy w oparciu o własne doświadczenia dydaktyczne starali się budować wykład i stosować efektywniejsze sposoby nauczania prawa od dotychczasowych (jak choćby K. Domaradzki). Wprowadzony przez KEN system sprawozdań i rodzaju dzisiejszych sylabusów dla wykładanych w szkołach wydziałowych przedmiotów miał ewidentnie swoje plusy w postaci zmuszenia wykładowców do przygotowywania samodzielnych wykładów i systematyzowania nauczanej materii. W zakresie przedmiotów prawniczych było to szczególnie ważne, głównie odnośnie do prawa krajowego, którego wykłady uniwersyteckie w Polsce dopiero były wprowadzane. Zestawienie treści nauczania przedmiotów prawniczych ze Szkoły Wydziałowej Poznańskiej wyraźnie wskazuje, iż

${ }^{71}$ Patrz przykładowo: projekt Wojciecha Prus Olszowskiego - W. Szafrański, O adwokatach w projekcie konkursowym do Kodeksu Stanistawa Augusta, [w:] Studia z historii ustroju i prawa. Księga dedykowana Profesorowi Jerzemu Walachowiczowi, pod red. H. Olszewskiego, Poznań 2002, s. 405-417; projekt J. Tomaszewskiego autora pracy „Adwokat polski za cnotą” z 1791 r., proponujący stworzenie Collegium Advocatorum. Taki system, tj. sformalizowanego kształcenia się młodych jurystów u patrona, przyjęty został w Polsce bardzo późno - wskazać można przykładowo na postanowienia w tym zakresie w ordynacji sądu ziemiańskiego województwa krakowskiego z 1 IV 1792 r. - patrz Archiwum Komisji Prawniczej t. VII, cz. 2, Kraków 1909, s. 297.

72 Patrz T. Woner, „Bunty” palestry w dobie upadku saskiego, „Palestra” 1959, nr 5, s. 52-58. 
wykłady z prawa znajdowały powiązanie między sobą, ale przede wszystkim były bardziej systematyzowane, a nie realizowane $\mathrm{w}$ formie przypadkowych treści czy wyimków z dzieł prawniczych. Powszechność „szkolnego” nauczania prawa w Poznaniu, nawet na poziomie średnim, to także pewien mit. Można by je nazwać raczej ,elitarnym”, zważywszy na liczbę uczniów, którzy uczęszczali na wykłady z wszystkich przedmiotów prawniczych, od czasu powstania Szkoły Wydziałowej, przez ponad 12 lat jej funkcjonowania. Ich liczba bowiem była mniejsza niż sto ${ }^{73}$. Jedyny kurs prawniczy, jaki się ówcześnie „opłacał”, to kurs prawa kanonicznego, który jednak w Szkole Wydziałowej nie był realizowany, gdyż powołana ona została dla innych celów niż kształcenie kanonistów. Znikoma liczba uczniów, którzy dotrwali do ostatniej klasy, w której kurs prawniczy był głównym kursem, to nie tylko efekt zbytnich kosztów, ale wspomnianego wyżej braku przełożenia nauczania szkolnego prawa na karierę prawniczą. Dodatkowym argumentem na poparcie tej tezy może być fakt, iż w przeciągu dwunastu lat do Szkoły Wydziałowej Poznańskiej żaden uczeń nie zapisał się wyłącznie do ostatniej klasy „,prawniczej”. Wszyscy nieliczni uczniowie, którzy odbyli kurs klasy szóstej, wcześniej byli co najmniej dwa lata w szkole, ucząc się od klasy III lub IV. Co pewien czas, zarówno ze szkół, jak i od wizytatorów wychodziły propozycje, aby wprowadzić zakaz przyjmowania do trybunałów i urzędów młodzieży, która nie legitymowała się świadectwem ukończenia szkoły, to jednak od czasu zgłaszania tych postulatów już w czasie początków funkcjonowania Rady Nieustającej, do ich realizacji na Sejmie Grodzieńskim nie tylko upłynęło sporo lat, ale przede wszystkim z uwagi na moment historyczny, brak było jakiegokolwiek widocznego efektu wprowadzenia takiego „spóźnionego” zarządzenia ${ }^{74}$.

\section{LEGAL EDUCATION IN POZNAŃ IN THE TIMES OF STANISLAW AUGUST PONIATOWSKI}

\section{Summary}

There were two schools of higher education in Poznan in the second half of the $18^{\text {th }}$ century: the Lubrański Academy and the Wielkopolska Academy (formerly a Jesuit College). When attempts to create a university had failed, in 1781 the two schools merged into one to form the Faculty School of Poznań. In comparison

${ }^{73}$ Nie można w tym przypadku jedynie zliczyć uczniów poszczególnych klas, gdyż część z nich ponownie uczyła się w tych samych klasach, a część pomimo zapisu do szkoły w kursach przez oba semestry nie uczestniczyła. Bardzo często uczniowie nie wracali do szkół po Wielkanocy.

${ }^{74}$ Patrz K. Mrozowska, Funkcjonowanie systemu szkolnego..., s. 234. 
to other faculty schools, the Poznań school boasted a high level of legal education, largely owing to the reforms in result of which legal subjects such as the laws of nature, political law, the law of nations, and national law in particular, were taught by lay teachers, such as Mateusz Mecherzyński and Kazimierz Domaradzki. However, to say the teaching of law even if only at a secondary level was common would be an exaggeration. Legal education was rather "elite", given the number (not even a hundred) of students who attended lectures in all legal subjects which the Poznan Faculty School offered for over 12 years of its operation. The only legal course which really counted at the time was canon law. The small number of students who would persevere to the last year in which law could be studied as a major was not only due to very high cost of such studies, but above all to the fact that legal education did not translate into a career in law. Many students fled to the Bar or the judiciary after just a year or two of study, with absolutely no legal knowledge learnt at school, and a very poor command of spoken and written Latin which was commonly used in the practice of justice in Poland.

\section{L'ENSEIGNEMENT DU DROIT À POZNAŃ À L'ÉPOQUE DU ROI STANISLAS AUGUST PONIATOWSKI}

\section{Résumé}

Pendant la deuxième moitié du XVIII ${ }^{\mathrm{e}}$ siècle à Poznań fonctionnent deux écoles: Akademia Lubrańskiego [Académie de Lubrański] et Akademia Wielkopolska (ancien collège des Jésuites). Malgré plusieurs tentatives, la création de l'université de Poznań n'aboutit pas, alors suite à la fusion des deux écoles susvisées, en 1781, naît définitivement une seule entité appelée Szkoła Wydziałowa Poznańska [École facultaire de Poznań]. Concernant l'enseignement du droit, par rapport à d'autres écoles de ce type, l'école poznanienne assure un haut niveau de prestation, notamment après la mise en place des changements, quand les matières juridiques telles que droits de la nature, droit politique, droit des nations, mais surtout droit intérieur, sont dispensées par des enseignants laïques, c'est le cas de Mateusz Mecherzyński ou Kazimierz Domaradzki, par exemple. Parler de l'universalité de l'enseignement du droit à Poznań, même au niveau de l'enseignement du second degré, serait un mythe. On pourrait parler plutôt d'un enseignement "élitaire ", étant donné le nombre d'élèves qui ont participé aux cours concernant l'ensemble des matières juridiques depuis la création de Szkoła Wydziałowa, et ensuite pendant plus de 12 années de son existence. Leur nombre n'atteint même pas 100 . La seule formation juridique qui paie à l'époque est celle du droit canon. Le nombre si peu élevé d'étudiants qui tiennent jusqu'à la dernière année d'études, où la formation juridique est une formation principale, résulte non seulement des coûts trop excessifs mais surtout du fait que l'enseignement scolaire du droit n'apporte pas l'effet escompté pour la carrière juridique. Ainsi, beaucoup d'étudiants choisissent les barreaux ou la justice au bout de un ou deux ans de 
formation à peine, ils quittent l'école n'ayant absolument aucune connaissance de droit, sachant à peine lire et écrire en latin, éléments pourtant toujours forts utiles dans la pratique de la justice en Pologne. En réalité, ces juristes sont à la recherche des parrains, mais les avocats ou magistrats, n'ayant pas acquis les compétences adéquates, n'ont pas l'intention de leur apprendre quoi que ce soit. 